\title{
International Journal of Food and Nutrition Research (ISSN:2572-8784)
}

\section{A Quantitative Assessment of the Nutritional Value of the Food for the School Nutrition Programme in KwaZulu-Natal Province, South Africa}

\section{Tafirenyika Mafugu $^{1}$ and Tecklah Usai ${ }^{2}$}

${ }^{1}$ Kwantebeni Comprehensive High School, Pinetown, South Africa

${ }^{2}$ Midlands State University, Zimbabwe

\section{ABSTRACT}

The aim of the study was to determine the nutritional value of the food for the school nutritional programme in one district in KwaZulu-Natal Province. A positivist research paradigm and a quantitative research approach were used in the study. Furthermore, a cross-sectional research design was utilized. The quantitative data was analysed using SPSS and Excel and was presented in texts and tables. The study found that the average daily intake per learner from the school nutrition programme was $218 \mathrm{Kcal}$ energy, $7.7 \mathrm{~g}$ of protein, $1.8 \mathrm{~g}$ of fat and $3.2 \mathrm{~g}$ of dietary fibre. These were all below $30 \%$ of RDA values. The observed mean protein, energy and vitamin $\mathrm{K}$ intakes per child per day were significantly lower than the expected mean intake for the nutrients. Intakes of other nutrients were within the limits of the prescribed amounts according to the menu quantity schedule. *Correspondence to Author: Tafirenyika Mafugu Kwantebeni Comprehensive High School, Pinetown, South Africa There were variations in the nutrient intake among learners in different schools due to inconsistent supply of food items by service providers.

\section{Keywords:}

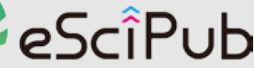

eSciPub LLC, Houston, TX USA.

school feeding programme, school nutrition, nutrients, nutritional Website: http://escipub.com/ value, balanced diet, recommended dietary allowances 


\section{BACKGROUND TO THE PROBLEM}

Due to poverty, several millions of children across the world at various schooling levels receive food at school every day to complement the nutrients in the food they eat at home (World Food Programme, 2016). In very poor countries, the school meal is mostly the major source of nutrients for the day. However, only a small number of children benefit from the school meals due to financial constraints for the school feeding programmes (World Food Programme, 2016). In some instances, the school nutrition programme is well structured with specific guidelines. However, these guidelines may be followed in developed countries like Finland and United States of America while poor countries like Mali provide school meals of lower standards and nutritional value due to insufficient funding (Aliyar, Gelli\& Hamdani, 2015; Hayes \& Berdan, 2013; Bundy, Woolnough, Burbano\& Drake, 2016). In some instances the food programmes fail to provide food significantly in areas that are hard-hit by hunger and poverty and the countries concerned need to improve their feeding programmes in such areas (African Union, 2015).

\section{School feeding programme in South Africa}

Buhl (2010), Department of Basic Education (2016) and Lacey (2012) indicate that one of the aims of the National School Nutrition Programme (NSNP) was to address certain micronutrient deficiencies through the provision of nutritious food in poor communities where there were severe nutrient deficiencies among children. In general, the NSNP targeted immense problems of malnutrition as well as micronutrient deficiency in Southern Africa (Caraher \& Coveney, 2016; Lacey, 2012; Department of Basic Education, 2009).

Aliyar, Gelli, and Hamdani (2015) observed that for all countries that had nutritional guidelines, there was no literature verifying the implementation of the guidelines and menus. Hochfeld, Graham, Stuart and Gent (2015) alleged that there was misappropriation of funds in the NSNP. Altman, Hart and Jacobs, (2009) assert that the most critical nutrient deficiencies for South Africa are vitamin A, lodine and iron (WHO, 2016). Furthermore, Health24 (2016) reveals that the prevalence of iron deficiency exists in both developed and developing countries resulting in more than $30 \%$ of the world's population being anaemic (Rendall-Mkosi, Wenhold and Sibanda, 2013). This triggered the researcher to assess the nutritional value of the food in the school nutritional programme as this would provide informed decisions on which quantities of food to provide in larger amounts.

\section{LITERATURE REVIEW}

Nutrition refers to the science of nutrients and how the nutrients interact with organisms to promote and maintain good health and it involves a set of processes that are essential for the body to utilize nutrients and perform various functions some of which result in growth (Joshi, 2010). Water and nutrients such as proteins, carbohydrates, fats, mineral salts and vitamins perform specific and critical functions in the body (Alters \& Schiff, 2009; Joshi, 2010).

Nutrition status refers to the condition of the body which results from successful utilisation of nutrients contained in food (Joshi, 2010). Good nutrition occurs when the body can make efficient use of food in a balanced diet. This is reflected through resistance to diseases, increased life span and good cognitive development (Joshi, 2010; Nabarro, Menon, Ruel and Yosef, 2012; USDA, 2015). Nutrition is influenced by age, religion, culture, economic status, genetics, medicine, health, technology and education (Berdanier, Dwyer \& Heber, 2014; Joshi, 2010). It is quite unfortunate to note people eat what they like and not what is influenced by awareness of the nutritive value of food.

Berdanier, Dwyer and Heber (2014) define dietary reference intakes as recommendations 
for nutrient intake for healthy people of all age groups, which are needed to prevent nutrient deficiencies and chronic diseases. They can be used to asses if nutrient intake is adequate. Dietary reference values that were used in the study are the recommended dietary allowances (RDA). The RDA is the average daily nutrient intake level that will meet the needs of half the population group (Berdanier, Dwyer \& Heber, 2014).

In sub-Saharan Africa, vitamin A, iodine, iron, zinc, and folate lack in a significant proportion of the population (Health24, 2016; Buhl, 2010). Sub-Saharan Africa, according to Health24, has the highest prevalence of vitamin A deficiency, which is the leading cause of childhood blindness. Although iodine deficiency can be prevented through food fortification including salt, Health24 (2016) notes that 324 million people in Africa, who included a significant number of school children had insufficient iodine intake in 2011. Aliyar, Gelli and Hamdani (2015) note that Vitamin C facilitates the absorption of iron, which makes it important to obtain enough vitamin $C$ to minimise the possibility of iron deficiency. Addressing micronutrient deficiency requires interventions which include fortification of food and greater dietary diversity (Berdanier, Dwyer \& Heber, 2014; Health24, 2016).

Rendall-Mkosi, Wenhold and Sibanda (2013) and Altman, Hart and Jacobs, (2009) assert that the most critical nutrient deficiencies for South Africa are vitamin A, lodine and iron. There is need to research how these deficiencies are being addressed. There are also problems of underweight, overweight and obesity (Tathiah, Moodley, Mubaiwa, Denny \& Taylor 2013). According to Tathiah et al. (2013) micronutrient deficiency in South Africa was partly caused by a shift from traditional diets rich in whole grain to diets rich in refined starch and sugars. High food prices in the poor communities must also have contributed the nutrient deficiencies. Shisana et al. (2014) posit that under-nutrition and over-nutrition in the South African population result from diet that mostly consists of cereals and limited animal protein and vitamin $A$ enriched vegetables and fruits. Although fortification programmes have been introduced to try and curb micronutrient deficiency, the programmes appear not to have significantly improved dietary diversity or macronutrient intake (Shisana et al., 2014).

The problems of underweight, overweight, obesity, lack of dietary diversity and low protein intake were also observed in a study by Adamu, Adjei and Kubuga (2012) in Tamale Metropolis in Ghana. The food provided in the school nutrition programme needs to be fortified with critical nutrients to alleviate problems associated with deficiencies of nutrients. Department of Basic Education (2009) and Bundy et al. (2009) highlight that maize meal should have a logo indicating that they have been fortified. However, fortified foods may be more expensive than non-fortified foods unless they are subsidised.

Unlike the menus in Mali which do not emphasize the consumption of fruits and vegetables menus in the Osun State School Feeding Programme in Nigeria are well structured. The menus are excellent if properly followed as they contain energy rich foods, protein rich foods, and vegetables or fruits everyday which are good sources of vitamins and minerals (Bundy et al., 2016). According to Laar (2016) Ghana School Feeding Programme are also structured. However, fruits are rarely used due to financial constraints. Moreover, there are no guidelines on the quantities of ingredients to be used per child or the serving per child.

\section{PURPOSE OF THE STUDY}

The objective of the study was to determine the nutritional value of the food served in the school nutritional programme in selected high schools in KwaZulu-Natal Province of South Africa.

\section{METHODOLOGY}


A post-positivist research paradigm was used in the study. A quantitative research approach and a cross-sectional research design were employed in the study. The methodology that was used in this study is discussed below.

\section{Permission and consent}

Permission for the research was obtained from the Head of Education Department in KwaZuluNatal and their respective district managers, circuit managers and school principals. Informed consent was obtained from all respondents.

\section{Population and sampling}

The quantitative population from one circuit consisted of 685 learners. The Quantitative sample size " $n$ " consisted of 63 girls and 45 boys giving a total of 108 learners in grade 12 from different schools. The sample of 108 learners was representative as it contained more than $10 \%$ of the learners in the quantitative population. Learners were selected from schools by systematic random sampling using class registers. Seven of the eight food suppliers and fifteen out of thirty food handlers also supplied information on quantities of different food items prepared per day in each school.

\section{Data Collection and Analysis}

\section{Investigator administered questionnaire}

structured

The investigator administered a structured questionnaire to collect data on food items consumed from learners. After an introduction, a consent form was given to the learners who had to read and sign to voluntarily participate in completing the questionnaire.

\section{Document analysis}

Documents that were analysed include the menu that was observed in the schools, menu quantities schedule, KwaZulu-Natal Province secondary school menu, Mnandi 4 sure recipe book and food specification guidelines for maize meal and soya mince. The documents were used to determine the expected quantities of food items which could not be provided in the questionnaire. The delivery notes were useful in verifying the quantities of food items that were provided by food handlers. The documents provided accurate quantities of food items delivered over a particular period of time and the information was used to verify quantities of food items which were provided by food handlers and service providers.

\section{DATA ANALYSIS}

The quantities of each food items prepared for the whole school were used to determine individual food intake over the week. The nutritional value of each food item consumed by an individual was determined using food composition tables. The total nutrient intake value was determined for the five days of the week. The total nutrient intake per week was then used to calculate the mean nutrient intake per learner per day in each school. The expected intake of each nutrient was calculated according to the district menu quantity guidelines schedule of the National School Nutrition Programme. Simple t-tests were performed to determine if there was any significant difference between the observed and expected nutrient intake values. The Paired sample $\mathrm{t}$-tests were also used to compare the observed nutritional value and the expected nutritional values of maize meal and soya mince. The Paired sample t-tests were also used to compare the observed nutrient intake data set per learner for each school and the expected nutrient intake data set.

The quantitative data were analysed using SPSS and excel. The data were used to calculate frequencies and percentages of learners according to their responses on the questionnaire.

\section{DATA PRESENTATION AND DISCUSSION}

This section presents the research data in texts, tables and pictures. The data was then discussed, conclusions and recommendations were made. 


\section{BIOGRAPHIC DATA OF RESPONDENTS}

The following sub-section presents the biographic data of learner respondents.

Table 4-3 shows that $45(41.7 \%)$ of the respondents were males and $63(58.3 \%)$ of the respondents were females. The total sample size was 108. A significant proportion of respondents had been in the same school for at least three years. The largest proportion 71 $(65.7 \%)$ had been in the same school for four years. The fact that most of the respondents were in the same school for at least three years resulted in more valid responses from the learners since they were more familiar with the programme. Their responses were based on observations made over a long period of time. The next section presents and analyses data in line with the research question that guided the study.

Table 0-1: Distribution of Biographical characteristics of grade 12 learner respondents $(\mathrm{N}=108)$

\begin{tabular}{|c|c|c|c|}
\hline Biography variable & Variable description & Frequency & Percentage (\%) \\
\hline \multirow[b]{2}{*}{ Gender } & Male & 45 & 41.7 \\
\hline & Female & 63 & 58.3 \\
\hline Total & & 108 & 100 \\
\hline \multirow[b]{2}{*}{ No of learners in Quintile } & Quintile 2 & 29 & 26.9 \\
\hline & Quintile 3 & 79 & 73.1 \\
\hline Total & & 108 & 100 \\
\hline \multirow[b]{3}{*}{ Age (years) } & $15-20$ & 96 & 88.9 \\
\hline & $21-25$ & 8 & 7.4 \\
\hline & No response & 4 & 3.7 \\
\hline Total & & 108 & 100 \\
\hline \multirow[b]{4}{*}{ Position of responsibility } & None & 88 & 77.8 \\
\hline & Class monitor & 19 & 17.6 \\
\hline & Others & 4 & 3.7 \\
\hline & & 1 & 0.9 \\
\hline Total & & 108 & 100 \\
\hline \multirow[b]{6}{*}{ Years in the same school } & 2 & 3 & 2.8 \\
\hline & 3 & 14 & 13.0 \\
\hline & 4 & 14 & 13.0 \\
\hline & 5 & 71 & 65.7 \\
\hline & More than 5 & 5 & 4.6 \\
\hline & No response & 1 & 0.9 \\
\hline Total & & 108 & 100 \\
\hline
\end{tabular}


QUANTITATIVE DATA BASED ON THE NUTRITIONAL VALUE OF THE FOOD SERVED TO LEARNERS IN THE SCHOOL NUTRITION PROGRAMME

This section presents the quantitative data obtained from learners which shows the food items consumed on different days. This data is presented in Table 4.13. The results on this section were based on the NSNP beneficiary's points of view: learners.

Subsequently, the average nutrient intakes per learner per school over the five days of the week are also presented. These were subjected to paired sample t-test. The observed nutrient data set for maize meal was also subjected to a paired sample t-test using expected nutrient data set for maize meal obtained through document analysis.

Food items consumed in the school nutrition programme

This section presents the data where learners confirmed that the food item was served in the school nutrition programme and the number of learners who liked or disliked the food item.

Table 0-2: Numbers and percentages of learners who confirmed the presence of the food items and the food items disliked by learners as well as the most liked food items

\begin{tabular}{|l|l|l|l|}
\hline Meal served & $\begin{array}{l}\text { No. \& \% of learners who } \\
\text { confirmed consuming the } \\
\text { food item }\end{array}$ & $\begin{array}{l}\text { No. \& of learners who } \\
\text { disliked the food item. }\end{array}$ & $\begin{array}{l}\text { No. \& \% of learners } \\
\text { who liked the food item } \\
\text { most. }\end{array}$ \\
\hline Monday & $106(98.1)$ & & \\
\hline Rice & $105(97.2)$ & $17(15.7)$ & $48(44.4)$ \\
\hline Fish & & & \\
\hline Tuesday & $105(97.2)$ & & \\
\hline Rice & $84(77.8)$ & $38(35.2)$ & \\
\hline Cabbage & $37(34.3)$ & $26(24.1)$ & \\
\hline Soya mince & & & $64(59.3)$ \\
\hline Wednesday & $34(31.5)$ & & $6(5.6)$ \\
\hline Butternut & $104(96.3)$ & $51(47.2)$ & \\
\hline Samp & $99(91.7)$ & $6(23.1)$ & \\
\hline Beans & & & \\
\hline Thursday & $102(94.4)$ & & \\
\hline Rice & $74(68.5)$ & $6(5.6)$ & \\
\hline Cabbage & $64(59.3)$ & & \\
\hline Soya mince & $93(86.1)$ & & \\
\hline Friday & $104(96.3)$ & & \\
\hline Mealie meal dish (phutu) & & \\
\hline Sour milk (amasi) & & & \\
\hline
\end{tabular}

Table 4.13 shows the number of learners who affirmed that the food item was part of the school nutrition programme and learners who were in favour or not in favour of the food item . 
Almost all learners 106 (98.1\%) and 105 $(97.2 \%)$ confirmed that they consumed rice and fish on Monday respectively. The consumption of rice on Tuesday and Thursday was confirmed by 105 (97.2\%) and $102(94.4 \%)$ respectively. Eighty-four learners (77.8\%) indicated that cabbage was consumed on Tuesday while $74(68.5 \%)$ confirmed the consumption of cabbage on Thursday. Consumption of soya mince was confirmed by 37 (34.32) on Tuesday and 64 (59.3\%) on Thursday. As many as $93(86.1 \%)$ and 104 $(96.3 \%)$ learners confirmed the consumption of phutuand sour milk respectively, on Fridays. Learners were able to mention the main meal components on each day. They hardly mentioned the presence of tomatoes, carrots and butternuts which were provided in small quantities.

A good number of learners 17 (15.7\%) disliked fish while $38(35.2 \%)$ disliked cabbage. A significant number of learners 26 (24.1\%) disliked soya mince while 51 (47.2\%) disliked samp. Twenty-five $(23.1 \%)$ disliked beans while $6(5.6 \%)$ disliked phutuand a similar proportion $6(5.6 \%)$ disliked amasi.
Amasi was the most liked food item which was most favoured by $64 \quad(59.3 \%)$ of the respondents, followed by fish which was liked most by $48(44.4 \%)$ of the respondents and samp liked by $14(13.0 \%)$ of the respondents. Only $6(5.6 \%)$ of the respondents indicated that beans was one of their most favourite meals.

The next section presents data based on the nutrient value of the food supplied in school nutrition programme.

\section{Summary of the nutritional value of food in the NSNP}

\section{Summary of the nutritional value of food in the NSNP}

The quantities of food items consumed enabled the researcher to determine the nutritional value of the food consumed in the school nutritional programme. Table 4.14 shows the nutritional values of various food items in $100 \mathrm{~g}$ of the food component. The information was obtained using food composition tables as well as nutritional values observed on food labels. The information was then used to determine the specific nutrient content of various foods quantities in 5 different schools shown in Table 4.15 .

Table 0-3: Food item and nutrient component of various foods served in the NSNP

\begin{tabular}{|c|c|c|c|c|c|c|c|c|c|c|c|c|c|c|}
\hline \multirow[b]{2}{*}{ Nutrient Component } & \multirow[b]{2}{*}{ 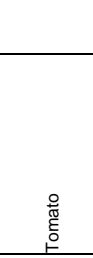 } & \multicolumn{13}{|c|}{ Food item and nutrient component per $100 \mathrm{~g}$} \\
\hline & & $\begin{array}{l}\frac{\bar{z}}{3} \\
\frac{0}{0} \\
\frac{0}{4} \\
\end{array}$ & 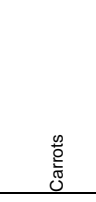 & 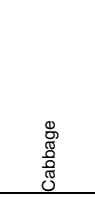 & 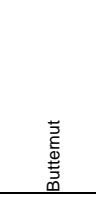 & 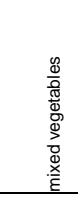 & 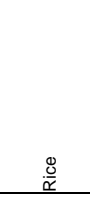 & 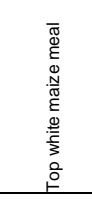 & 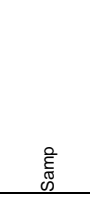 & 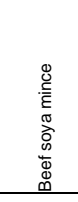 & 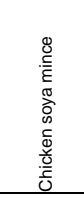 & $\frac{c}{i_{i}^{2}}$ & 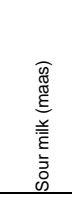 & 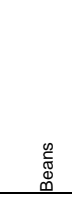 \\
\hline Energy (Kcal) & 18 & 52 & 41 & 25 & 45 & 37 & 282.0 & 334.1 & 358.0 & $\begin{array}{l}332 . \\
46\end{array}$ & $\begin{array}{l}353 . \\
5\end{array}$ & $\begin{array}{l}104 . \\
7\end{array}$ & 59.8 & $\begin{array}{l}346 . \\
6\end{array}$ \\
\hline Carbohydrates (g) & 3.9 & 13.81 & 9.58 & 5.8 & 11.69 & 7.3 & 64 & 72.5 & 79.2 & 52.0 & 53 & 2 & 4.0 & 65.6 \\
\hline Protein $(\mathrm{g})$ & 0.9 & 0.26 & 0.93 & 1.3 & 1.0 & 1.4 & 8.7 & 6.3 & 7.1 & 15.5 & 21.1 & 17 & 3.0 & 16.9 \\
\hline Total Fat (g) & 0.2 & 0.17 & 0.24 & 0.1 & 0.1 & 0.2 & 0.4 & 0.9 & 0.8 & 5.2 & 7.0 & 5.1 & 3.3 & 1.3 \\
\hline Cholesterol (mg) & 0 & & 0 & 0 & 0 & 0 & $<0.1$ & $<1$ & & & & 68 & 9 & \\
\hline Dietary Fiber (g) & 1.2 & 2.4 & 2.8 & 2.50 & 2 & 3.1 & 1.1 & 3.1 & 6.2 & 5.7 & 7.0 & 2.3 & 0.2 & 19.4 \\
\hline \multicolumn{15}{|l|}{ Vitamins } \\
\hline Folates $(\mu \mathrm{g})$ & 15 & 3 & 19 & 53 & 27 & 18 & 70 & 200 & & & & & & \\
\hline Niacin (mg) & 0.594 & 0.091 & 0.983 & 0.234 & 1200 & 0.5 & 5.1 & & 1.1 & & & & & \\
\hline
\end{tabular}


Tafirenyika Mafugu and Tecklah Usai, IJFNR, 2019; 3:25

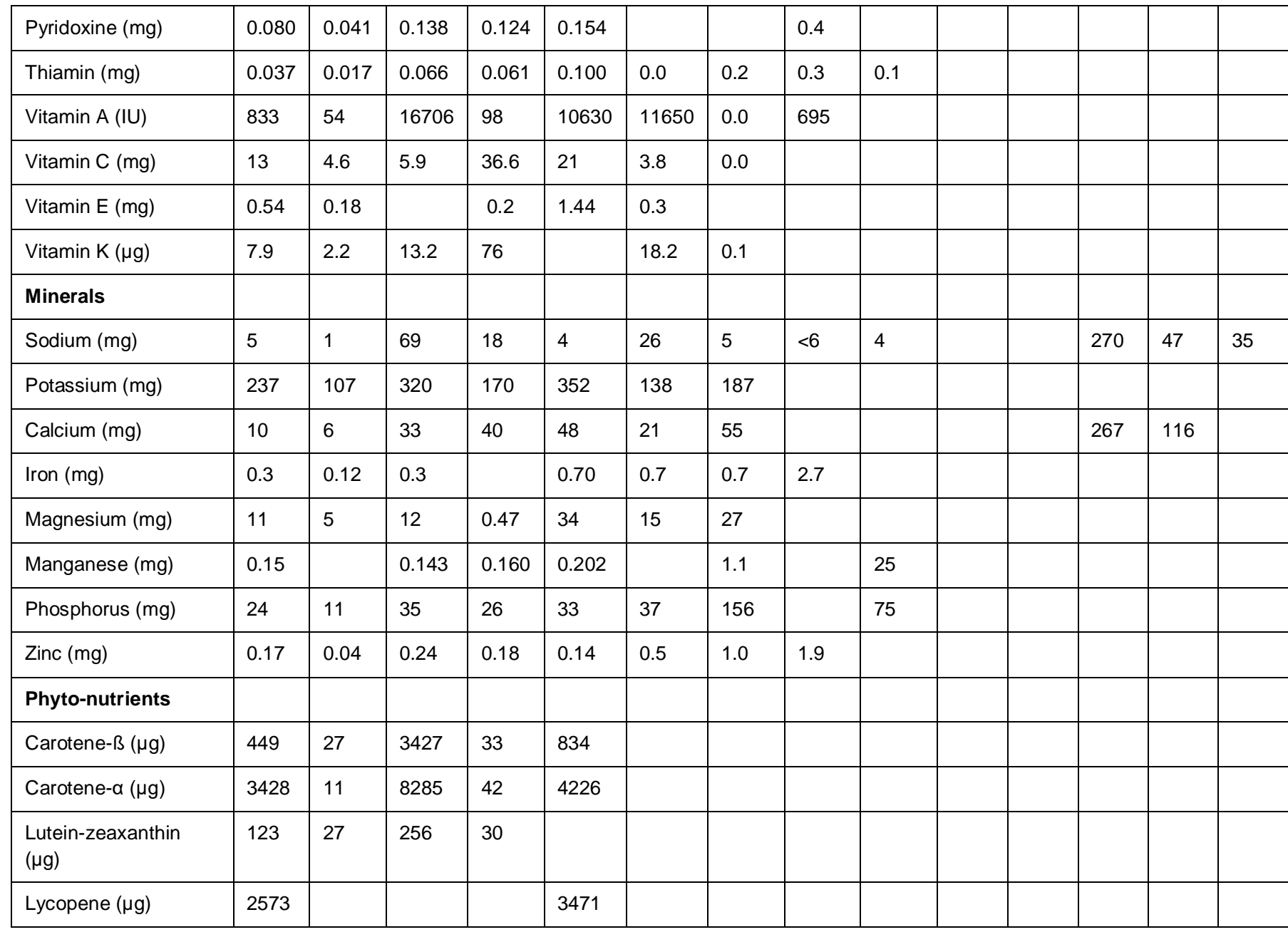

(Rudrappa, 2009-2017; South African Food Data System, 2015; CONDE NAST 2014)

Table 4.14 reflects that rice, maize meal, samp, soya mince and beans were the major sources of energy with rice providing 282.0 kilocalories of energy and samp 358.0 kilocalories per $100 \mathrm{~g}$ of food item, while maize meal, soya mince and beans had energy values in between the values for rice and samp. The foods with high energy values had high corresponding carbohydrate content with rice providing $64.0 \mathrm{~g}$ of carbohydrates per $100 \mathrm{~g}$ of food component and samp having the highest value of $79.2 \mathrm{~g}$ of carbohydrates per $100 \mathrm{~g}$ of food component. Proteins were abundant in beef $(15.5 \mathrm{~g})$, chicken soya mince (21.1g), fish (17g) and beans $(16.9 \mathrm{~g})$ per 100 grams of food item. Chicken and beef soya mince, fish and sour milk (maas) had relatively high fat content $(7.0 \mathrm{~g}, \quad 5.2 \mathrm{~g}, \quad 5.1 \mathrm{~g}$ and $3,3 \mathrm{~g}$ respectively) compared to other foods in the NSNP. The highest amount of fat was obtained from sunflower cooking oil where one tablespoon $(15 \mathrm{ml})$ contained $13.6 \mathrm{~g}$ of fat and 120 kilocalories of energy. Dietary fibre was relatively high in samp $(6.2 \mathrm{~g} / 100 \mathrm{~g})$, beef mince $(5.7 \mathrm{~g} / 100 \mathrm{~g})$, chicken mince $(6.0 \mathrm{~g} / 100 \mathrm{~g})$ and beans having the highest content of $19.4 \mathrm{~g}$ per $100 \mathrm{~g}$ of beans. Carbohydrates, fats, proteins and fibre were generally abundant in rice, samp, phutu, soya mince, fish, sour milk and beans.

Vitamins and mineral elements were also provided by the food in the school nutrition programme. Top white maize meal supplied the highest amount of folate $(200 \mu \mathrm{g} / 100 \mathrm{~g})$ with rice, cabbage and butternut providing $70 \mathrm{~g}, 53 \mathrm{~g}$ and $27 \mathrm{~g}$ per $100 \mathrm{~g}$, respectively. Butternut provided a distinctively high amount of niacin $(1200 \mathrm{mg} / 100 \mathrm{~g})$ compared to all other foods in the table which provided quantities that were 
less than $5.2 \mathrm{mg}$ per $100 \mathrm{~g}$. The highest amounts of pyridoxine $(0.4 \mathrm{mg} / 100 \mathrm{~g})$ and thiamine $(0.3 \mathrm{mg} / 100 \mathrm{~g})$ were contained in top white maize meal. Fruits and vegetables were the major sources of vitamin A with carrots containing 1670IU, mixed vegetables $11650 \mathrm{IU}$, butternut 1063IU, tomato 833IU, top white maize meal 695IU, and cabbage 98IU per 100 grams of the food item. Vitamin $C$ was richly supplied by cabbage $(36.6 \mathrm{mg})$, butternut $(21 \mathrm{mg})$, tomatoes $(13 \mathrm{mg})$ and apple fruit and carrots containing between $4 \mathrm{mg}$ and $6 \mathrm{mg}$ per $100 \mathrm{~g}$ of the food component. Butternut contained the highest amount of vitamin $E$ $(1.44 \mathrm{mg})$ while cabbage contained the highest amount of vitamin $\mathrm{K}(76 \mu \mathrm{g})$ per 100 grams. Sodium was more abundant in fish (270mg), carrots $(69 \mathrm{mg})$ and sour milk $(47 \mathrm{mg})$ while potassium was generally abundant in all fruits and vegetables, as well as in rice; with nutrient content values between $100 \mathrm{mg}$ and $360 \mathrm{mg}$ per $100 \mathrm{~g}$. Calcium was rich in fish $(267 \mathrm{mg})$ and milk (116mg) with moderate amounts in vegetables between $30 \mathrm{mg}$ and $60 \mathrm{mg}$ per $100 \mathrm{~g}$. Top white maize meal, mixed vegetables, rice and butternut had relatively large amounts of iron with $2.7 \mathrm{mg}$ in maize meal and $0.7 \mathrm{mg}$ per $100 \mathrm{~g}$ in each of the three successive food items. Magnesium was mostly supplied by butternut $(34 \mathrm{mg})$ and rice $(27 \mathrm{mg})$ while manganese was rich in samp $(25 \mathrm{mg})$. All fruits and vegetables had phosphorous amounts between $10 \mathrm{mg}$ and $40 \mathrm{mg}$ and the foods with the most abundant phosphorous were rice (156mg) and samp (75mg). Maize meal and rice had the highest quantities of zinc which were $1.9 \mathrm{mg}$ and $1.0 \mathrm{mg}$ per $100 \mathrm{~g}$ respectively. Carotene was generally abundant in fruits and vegetables with carrots and butternuts being the richest sources. Fruits and vegetables were the major sources of vitamins and mineral salts with fortified maize meal supplying reasonable amounts of zinc and iron. lodated salt which was used in all schools but has not been included in the table was the major source of iodine. The nutritional value information which was observed on various food labels in the schools visited and food composition tables from various sources, assisted the researcher in determining the nutritional value of various food items.

Table 4.14 shows the general nutrient contents of the various food items that were consumed in the school nutrition programme. The information was then used to determine the specific nutrient content of various foods quantities in the 5 different schools shown in Table 4.15.

Table 4.15 shows the average nutrient intake per child per day in the five different schools, as well as the percentage of RDA for that specific nutrient for adolescents between 14 and 18 years old. The table also shows the overall mean nutrient intake per child per day for the five schools. The highest energy intake per child was in school B where the intake was 277.2 kilocalories per day, and the lowest consumption of energy was in school C (158.6 kilocalories per learner per day). All the schools had energy intake above 227 kilocalories per learner per day except school $\mathrm{C}$. The maximum percentage of RDA for energy was $13.9 \%$ for school B while the minimum was $7.9 \%$ for school C. The mean energy intake for learners in all schools was 218.8 kilocalories $(10.9 \%$ of RDA value). The standard deviation for energy was 46.8 kilocalories. This indicates that the mean kilocalories intakes per learner per day for the five schools were spread far from the overall mean and the nutrient intake values of the different schools were spread over a wide range of values. The mean kilocalorie intakes per learner per day for different schools were very different from each other, although there were guidelines on the quantities to purchase which corresponded with the number of learners.

The protein content was almost equally high in school $B$ and $C$ where the intake was $9.7 \mathrm{~g}$ and $9.8 \mathrm{~g}$ respectively, corresponding to an equal RDA value of $20 \%$. The mean protein intake 
Tafirenyika Mafugu and Tecklah Usai, IJFNR, 2019; 3:25

Table 0-4: The nutrient intakes per child per school and the \% RDA for each nutrient for adolescents (14-18 years)

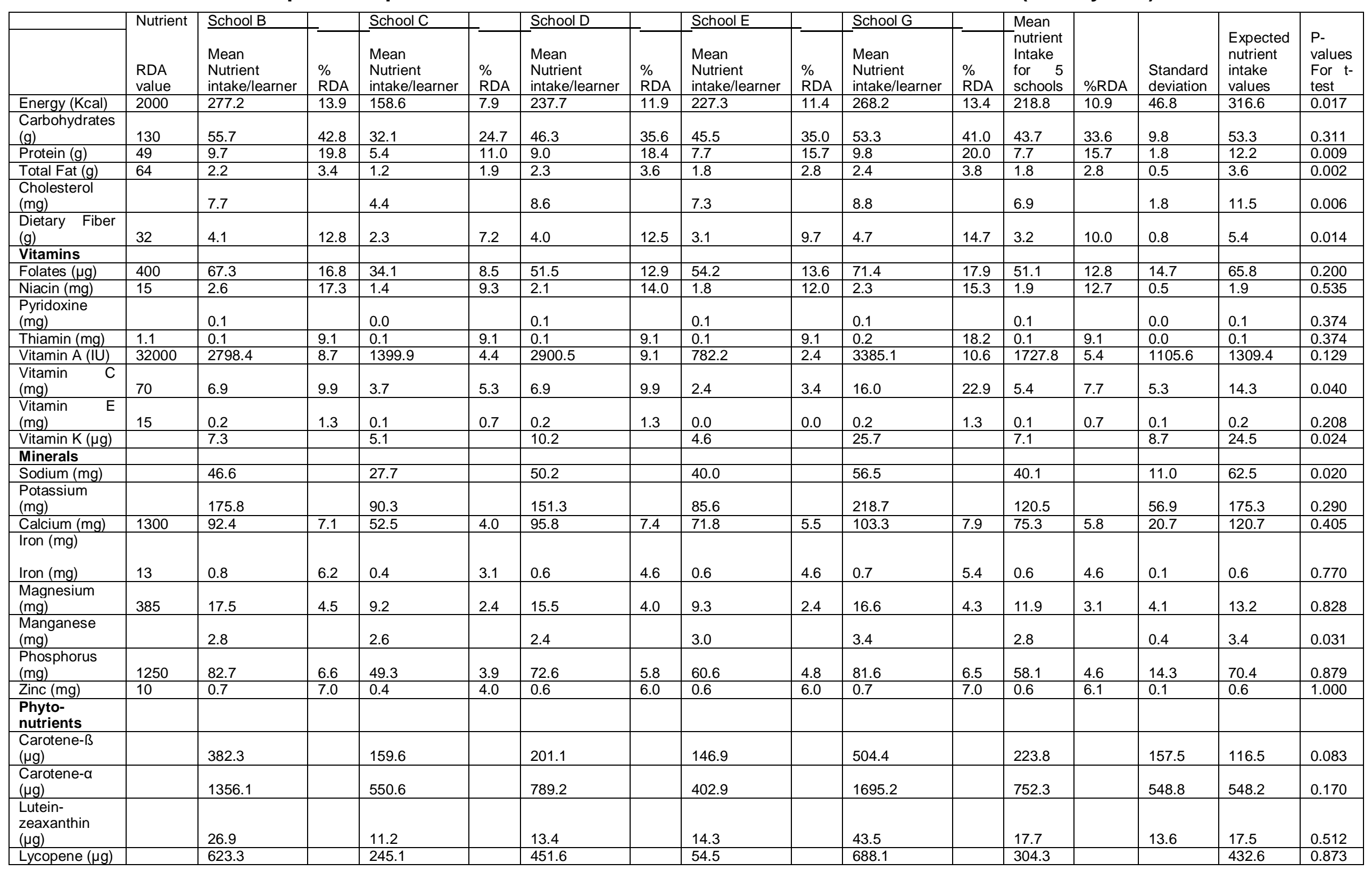

IJFNR: http://escipub.com/international-journal-of-food-nutrition-research/ 
was $7.7 \mathrm{~g}(15.7 \%$ of RDA). A standard deviation of $9.8 \mathrm{~g}$ indicates that the mean carbohydrates intake values per learner per day for different schools were more dispersed.

Generally, there was low fat content which was less than 4 percent $(2.56 \mathrm{~g})$ of the fat RDA value in all five schools with a mean intake per child per day of $3.2 \mathrm{~g}(5 \%$ of RDA). The amount of dietary fibre was between $2.3 \mathrm{~g}$ and $4.7 \mathrm{~g}$ which corresponded to $7.2 \%$ and $14.7 \%$ of the fibre RDA value respectively. The folate intake was between $8.5 \%(34.1 \mu \mathrm{g})$ and $17.9 \%(71.4 \mu \mathrm{g})$ of the folate RDA value with a mean intake of $51.1 \mathrm{\mu g}(12.8 \%)$ while thiamin intake was between $9.1 \%(0.1 \mathrm{mg})$ and $18.2 \%(0.2 \mathrm{mg})$ of thiamin RDA value with a mean intake of $0.1 \mathrm{mg}$ $(9.1 \%)$. The highest vitamin $A$ intake was $3385.1 \mathrm{IU}(10.6 \%$ of RDA) in school $\mathrm{G}$ and the lowest intake was in school $E$ with an intake of $782.2 \mathrm{IU}$ (2.4\% of vitamin A RDA value). The mean vitamin $A$ intake for all the schools was $1727.8 \mathrm{IU}$ ( $5.4 \%$ of RDA). A very large standard deviation of $1105.6 \mathrm{IU}$ indicates that the mean vitamin A intakes per school per child were more dispersed.

The consumption of vitamin $E$ was very low in all schools with a mean intake of $0,1 \mathrm{mg}$ which is equivalent to $0.7 \%$ of the RDA value. A small standard deviation of $0,1 \mathrm{mg}$ for vitamin $\mathrm{E}$ indicates that the mean intake values for the five different schools were closely clustered around the overall mean intake value for all the schools.

The consumption of calcium was between 52.5 $\mathrm{mg}(4.0 \%$ of RDA) and $95.8 \mathrm{mg}$ (7.4\% of RDA) with a mean of $75.3 \mathrm{mg}(5.6 \%$ of RDA), while that of iron was between $0.4 \mathrm{mg}(3.1 \%)$ and $0.8 \mathrm{mg}(6.2 \%)$ with an overall mean of $0.6 \mathrm{mg}$ (4.6\% of RDA). The intake of zinc was between $0.4 \mathrm{mg}(4.0 \%$ of RDA) and $0.7 \mathrm{~g}(7.0 \%$ of RDA) with a mean intake of $0.6 \mathrm{~g}(6.0 \%$ of RDA) and that of magnesium was between $9.2 \mathrm{mg}(2.4 \%$ of RDA) and $17.5 \mathrm{mg}$ ( $4.5 \%$ of RDA value), while that of phosphorous was between $49.3 \mathrm{mg}$ $(3.9 \%$ of RDA) and $82.7 \mathrm{mg}(6.6 \%$ of RDA) with a mean intake of $58.1 \mathrm{mg}$ ( $4.5 \%$ of RDA). Standard deviations between $4.0 \mathrm{mg}$ and $7.9 \mathrm{mg}$ indicate that the mean nutrient intakes for these minerals, among schools, were widely dispersed.

\section{HYPOTHESIS TESTING: T-TEST}

The t-test was used to compare paired data test and to compare one data set from the expected mean. The paired sample t-test and one sample t-test were used to come up with conclusions based on the observed nutrient intakes.

\section{Paired sample t-test}

This test was performed to compare the observed and expected nutrient data sets for maize meal as well as soya mince. The same test was performed to determine if there was any significant difference between the observed average nutrient intake data set for each school and the expected nutrient intake data set according to the menu quantity schedule.

\section{Paired sample t-test for maize meal}

$\mathrm{H}_{0}: \mathrm{U}_{1}=\mathrm{U}_{2}$. There was no significant difference between the observed nutrient value and the expected nutrient value for maize meal according to the menu quantity schedule.

$\mathrm{H}_{1}: \mathrm{U}_{1} \neq \mathrm{U}_{2}$ There was a significant difference between the observed nutrient value and the expected nutrient value for maize meal.

Degrees of freedom: $\quad D_{f}=12+12-2=22$

$\alpha$ at $5 \%$ significant level and 2 tailed test

$$
\alpha=0.05 / 2=0,025
$$

Critical value 2.074

$P$ value $=0,056>\alpha$

There was no statistically significant difference between the observed nutrient values and the expected nutrient values for maize meal. The differences observed were only due to chance. The mealie meal used met the expected nutrient values.

\section{Paired sample t-test for soya mince}


This section presents the paired sample t-test similar to the expected soya mince according to for soya mince to check if the nutrient the food specification guidelines.

composition of the supplied soya mince is

Table 0-5: Observed and expected nutrient of maize meal

\begin{tabular}{|l|l|l|}
\hline \multicolumn{2}{|l|}{} & Nutrient value \\
\hline Nutrient & Expected & Observed \\
\hline Energy (Kcal) & 334,6 & 334,1 \\
\hline Carbohydrates(g) & 75 & 72,5 \\
\hline Protein (g) & 8 & 6,3 \\
\hline Fat (g) & 1 & 0,9 \\
\hline Dietary Fibre (g) & 3 & 3,1 \\
\hline Vitamin A & $10 \%$ & $2,30 \%$ \\
\hline Thiamin & $10 \%$ & $25 \%$ \\
\hline Riboflavin & $7 \%$ & $15 \%$ \\
\hline Vitamin B6 & $10 \%$ & $24 \%$ \\
\hline Folic acid & $25 \%$ & $50 \%$ \\
\hline Iron & $10 \%$ & $21 \%$ \\
\hline Zinc & $8 \%$ & $17 \%$ \\
\hline & $\mathrm{p}-\mathrm{value:}$ & 0,056395 \\
\hline
\end{tabular}

(Expected values extracted from Department of Basic Education, 2016)

Table 0-6: Observed and expected nutrient of soya mince

\begin{tabular}{|l|l|l|}
\hline & Nutrient value & \\
\hline Nutrient & Expected & Observed \\
\hline Energy (Kcal) & 1479 & 1365 \\
\hline Protein (g) & 21,1 & 24 \\
\hline & & \\
\hline Dietary Fibre (g) & 7 & 4 \\
\hline & p-value: & 0,42253 \\
\hline
\end{tabular}

(Expected values extracted from Department of Basic Education, 2016)

$\mathrm{H}_{0}: \mathrm{U}_{1}=\mathrm{U}_{2}$ There was no significant difference between the observed nutrient value of soya mince and the expected nutrient values (The nutrient values for the two data sets were similar)
$\mathrm{H}_{1}: \mathrm{U}_{1} \neq \mathrm{U}_{2}$ There was a difference between the observed nutrient intake data set and the expected nutrient intake data set for soya mince. 
D freedom $=3+3-2=4$

$\alpha=\frac{0.05}{2}=0.025$

Critical value $=2,776$

$P$ value $=0.423>\alpha$

There was no statistically significant difference between the two data sets. The soya mince supplied met the expected nutrient requirements.

Paired sample t-test for the observed average nutrient intake data set for each school and the expected nutrient intake data set according to the menu quantity schedule

The average nutrient data sets for schools $\mathrm{B}, \mathrm{C}$, $D, E$ and $G$ were compared with average nutrient intake data set according to NSNP menu quantities formula schedule obtained from schools. The data sets that were used to perform the t-test are presented in Table 4.15.

$\mathrm{H}_{0}: \mathrm{U}_{1}=\mathrm{U}_{2}$ There was no significant difference between the observed average nutrient intake data set for each school and the expected nutrient intake data set according to the menu quantity schedule.

$\mathrm{H}_{1}: \mathrm{U}_{1} \neq \mathrm{U}_{2}$ There was a significant difference between the observed nutrient intake data set for each school and the expected nutrient intake data set.

Degrees of freedom $=26+26-2=50$

critical value $=2.009$ at $5 \%$ significance level and 2 tailed test. $\quad \alpha=\frac{0.05}{2}=0.025$

All p-values of 0.125 for school $B, 0.068$ for School C, 0.289 for school D, 0.046 for school $E$ and 0,110 for school $G$ were greater than the $\alpha$-value of 0.025 . Therefore, for all the 5 schools, the average nutrient intakes were in line with quantities specified by the formula schedule. The differences observed between the data set for each school and the expected data set was only by chance. There was no statistically significant differences in nutrient intakes between the paired sample data sets (i.e. school B observed nutrient data set \& expected nutrient data set; school $\mathrm{C}$ observed nutrient data set \& expected nutrient data set; school D observed nutrient data set \& expected nutrient data; school $\mathrm{E}$ observed nutrient data set \& expected nutrient data; school G observed nutrient data set \& expected nutrient data).

One sample t-test to compare the mean nutrient intakes in schools with the expected mean nutrient intake

One sample t-test was also performed to determine whether there was any significant difference between the observed mean nutrient intakes per learner per day in different schools and the expected specific mean nutrient intake per learner per day in each school according to the formulae schedule. For example, the kilocalorie intakes for five schools: $272.2 \mathrm{Kcal}$ for school B; 158.6Kcal for school C; $237.7 \mathrm{Kcal}$ for school D; 227.3Kcal for school $E$; and 268.2Kcal for school G, were compared with the expected mean of $326.6 \mathrm{Kcal}$. The t-test was performed for all nutrients in Table 4.15 and the $\mathrm{p}$-values are shown in the same table.

For all the nutrients, the null hypothesis was using the example of kilocalories: $\mathrm{H}_{0}: \mathrm{U}_{1}=\mathrm{U}_{2}$ There was no significant difference between the data set for the observed mean kilocalories intakes per child per day for each of the schools $(B, C, D, E$ and $G$ ) and the expected mean kilocalories intake per child per day.

The alternative hypothesis:

$\mathrm{H}_{1}: U_{1} \neq \mathrm{U}_{2}$ There was a significant difference between the observed mean kilocalorie intake data set for schools and the expected mean kilocalorie intake.

The same null hypothesis and alternative hypothesis were used for all the nutrients shown in Table 4.15.

Using 5 percent significance level and two tailed test:

$\alpha=\frac{0.05}{2}=0.025$. 


\section{P-values for t-test comparing observed and expected intakes}

The $p$-values in Table 4.15 for energy, protein, total fat, cholesterol, dietary fibre, vitamin $\mathrm{K}$ and sodium were less than the $\alpha$-value of 0.025 . There was enough evidence to infer that the observed mean intakes per child per day for energy, protein, total fat, cholesterol, dietary fibre, vitamin $\mathrm{K}$ and sodium were significantly different from the expected mean nutrient intakes. The intakes of these nutrients were far less than the expected intakes. For all the other nutrients, the $p$-values are greater than the $\alpha$ value of 0.025 . Therefore, there was no significant difference between the observed nutrient intakes and the expected nutrient intakes.

\section{DISCUSSION OF RESEARCH RESULTS}

\section{Energy Value}

This section focuses on the nutritional value of food. The percentage energy (kilocalories) intake in the five schools from which qualitative data was collected was between $7.9 \%$ and $13.9 \%$ of the recommended dietary allowance (RDA). According to the menu quantities schedule, the expected energy intake was 316.6 kilocalories, which was $15.8 \%$ of the RDA. In the one sample t-test to compare the observed energy intake and expected energy intake, a $p$-value of 0.017 revealed that there was a significant difference between the observed mean kilocalories intake data set for schools and the expected mean kilocalories intake according to menu quantities schedule. According to the Department of Basic Education South Africa (2009), the energy intake was expected to be at least $30 \%$ of the RDA. It was worrisome to note that the expected energy intake of $15.8 \%$ of the RDA was far below the $30 \%$ value recommended by the Departments of Basic Education (2009).

Aliyar, Gelli and Hamdani's (2015) study of the nutritional guidelines and menu compositions for school feeding programmes in 12 countries revealed expected energy (kilocalories) intakes between $30 \%$ and $45 \%$ of the RDA for developed and developing countries. All the expected values for high income, middle income and low income countries were far above all the observed intake values for all the five schools in KwaZulu-Natal in South Africa, which is a middle income country. However, Aliyar, Gelli and Hamdani's (2015) study relied only on documented data on nutritional guidelines and menu composition and not the actual data obtained from schools as in this study. The actual intake values in the schools in these countries could have been less than the expected intakes. Furthermore, it was disappointing that the expected energy intake, according to the menu quantities schedule, was also below all the percentage RDA intake values for the high income countries, middle income as well as low income countries, according to Aliyar Gelli and Hamdani (2015). Learners in low and middle income countries generally need more energy as they sometimes travel over long distances to schools. Hence, there is need to increase energy intakes to match international standards.

Although there were significant differences between the expected energy intake and the actual energy intake in schools, the paired sample t-tests $p$-values that compared the nutrient intake data sets for each school and the expected nutrient intake data set, indicated that there was no significant difference between the expected nutrient intake data set and observed intake data sets in all schools. This meant that most of the schools were supplying quantities of food items that were close to the expected quantity as prescribed by the menu quantities schedule. However, it is disappointing that these expected standards are lower than the standards set by low income countries.

According to the Department of Education (2016), the maize meal to be supplied in schools was to be fortified and the minimum expected nutritional value was outlined in the 
food specification guidelines. When a paired sample t-test was performed, the $p$-value obtained revealed that the nutritional value of the maize meal supplied to the schools was not significantly different from the nutritional value specified in the food specification guidelines. This means that the maize meal that was supplied to the schools was in line with the food specification guidelines of the NSNP.

\section{Protein Value}

Findings from quantitative data revealed that the percentage of protein intake in the five schools from which both qualitative and quantitative data were collected was between $11.0 \%$ (school C) and $20.0 \%$ (school G) of the recommended dietary allowance, with an average protein intake of $7.7 \mathrm{~g}(15.7 \%$ the RDA) which is lower than the expected protein intake of $12.2 \mathrm{~g}(24.9 \%)$. A one sample t-test performed to compare the observed protein intake values in the five schools and the expected protein intake yielded a $p$-value of 0.009 . This low $p$-value for the t-test shows enough evidence to infer that the observed mean protein intake per child per day of $7.7 \mathrm{~g}$ was significantly lower than the expected mean nutrient intake of $12.2 \mathrm{~g}$ per child per day. It was also worrisome to note that the expected protein intake determined using the menu quantities schedule was below the minimum amount of $30 \%$ of the RDA which was recommended by the Department of Basic Education (South Africa) (2009). This was probably limited by a small budget of $R 3.25$ per learner per day which is much lower than the budgets of between R4.00 and R33.00 for the nutrition programmes in Aliyar, Gelli and Hamdani's (2015) study of developing and developed countries. Such high budgets could make it possible to meet the expected protein and other nutrient needs for the learners.

The nutritional value of soya mince from the food specification guidelines by the Department of Basic Education (2016) was compared with the observed nutritional value of soya mince that was used in schools met the recommended standards.. This was done by the use of a paired sample t-test which compared the observed nutrient data set and the expected nutrient data set of soya mince. A p-value of 0.423 revealed that the expected nutrient data set of soya mince was not statistical significantly different from the observed nutrient data set of soya mince. Soya mince, beans and fish contain significant amounts of energy. Sugar beans also contain a large amount of dietary fibre (South Africa Food Data System, 2015). Pilchard fish are also very rich in omega3 fatty acids, vitamin $A, B, C, D$ and $E$, as well as minerals such as iron, calcium, magnesium and phosphorous The nutrient interaction help to maintain good cholesterol levels, which is important in sustaining good heart health and reducing the risk of stroke and cardiovascular diseases. Vitamin $B_{12}$, also found in fish, protects the walls of the arteries and promotes cardiovascular health (Watson \& Preedy, 2013).

\section{Vitamin and Mineral Value}

One sample t-tests performed to compare if there were significant differences between the data sets for each mineral and vitamin intake in different schools and the expected intake, revealed that all the observed data sets for vitamins and minerals intakes were not statistically significantly different from the expected intake values. This was reflected by large $p$-values which were greater than the $\alpha$ value of 0.025 . However, the average intake of vitamins $\mathrm{K}$ and sodium were significantly different from the expected value. The intake of sodium could probably have been high if the quantity of salt (sodium chloride) intake was included in the determination of nutrient intake. The intake of sodium chloride could not be considered since the food handlers were unable to specify the quantities of sodium chloride added in each meal. The average intakes of vitamins were below $13 \%$ of the RDA while that of minerals was below $10 \%$ of the 
recommended dietary allowances. Such intake levels, according to The values determined from the menu quantities schedule are much lower than the $30 \%$ of RDA values suggested by the (Aliyar, Gelli and Hamdani's 2015 and Department of Basic Education 2016). Increasing the consumption of vitamin A-rich carrots \& butternuts as well as vitamin C-rich tomatoes and cabbage increases the vitamins and mineral intake. The intake of vitamin $A$ and iron that were found to be deficient in the South Africa population, according to Altman, Hart and Jacobs, (2009); Buhl (2010) andRendallMkosi, Wenhold and Sibanda (2013), were also found to be low in this study.

\section{CONCLUSIONS}

In the five schools $B, C, D, E$ and $G$, the average nutrient intakes per learner per day for energy, total protein, fat and dietary fibre were less than $30 \%$ of the RDA. Respondents and participants confirmed that the main sources for macronutrients were rice, samp, phutu and freckled sugar beans and soya mince.

There was a significant difference between the observed mean kilocalories intake data set for schools and the expected mean kilocalories intake according to menu quantities schedule.

The observed mean protein intake per child per day of $7.7 \mathrm{~g}$ was significantly lower than the expected mean nutrient intake of $12.2 \mathrm{~g}$ per child per day.

The average intake of vitamins $\mathrm{K}$ and sodium were significantly different from the expected value. The observed data sets for other vitamins and minerals intakes were not statistically significantly different from the expected intake values.

Study findings revealed that the main sources of vitamins and mineral salts were iodated salt, cabbage, carrots, butternuts, tomatoes, phutu and, in some instances, mixed vegetables which were supplied in low quantizes.

The t-tests results revealed that the observed mean intakes per child per day for energy, protein, total fat, cholesterol, dietary fibre, vitamin $\mathrm{K}$ and sodium were significantly different from the expected mean nutrient intakes. The t-tests also indicated that the observed intakes of all other nutrients were not statistically significantly different from the expected nutrient intakes. The nutritional value of the foods was quite variable. There were variations in the nutrient intake among learners in different schools due to unequal intake of food items by learners in different schools. There was inconsistent supply of food. The intakes of all nutrients were below the minimum of $30 \%$ of RDA which was recommended by the Department of Basic Education.

\section{RECOMMENDATIONS}

The mean energy intake needs to be increased so as to meet the required energy intake prescribed in the menu quantity schedule.

There is need to increase the intake of soya mince, fish and beans so as to meet the expected protein intake according to the menu quantities schedule.

The vitamin $\mathrm{K}$ and dietary fibre intake could be increased by increasing the intake of cabbage, carrots and mixed vegetables which are rich in vitamin $\mathrm{K}$ as well as dietary fibre.

\section{Conflict of Interest Statement}

Tafirenyika Mafugu and Teclah Usai are committed to integrity and fairness in the conduct of all activities in line with research. Inevitably, the interests of the co-authors will involve them in all processes of publication and review. This conflict of interest statement is intended to give guidance on disclosure of conflicts. This conflict of interest statement applies to the co-authors. This publication was not funded by any institution or organization.

- The co-authors have the duty to place the interest of the publishers foremost and will try to meet the required standards. This accountability supersedes any conflicting loyalty to personal interests, or paid or volunteer service to other organizations. 
- Not any single person will derive any personal profit or gain, directly or indirectly, by reason of his or her service towards the publication of the article

- Coauthors may not obtain for themselves, their relatives, or their friends a material interest of any kind from their association with publishers

- If a co-author has an interest in reproducing any part of the publication he or she must make full disclosure of such interest before any reproduction.

- Not any one of the co-authors may accept any payment of the article from a grantee, potential grantee, or supplier, except nominal hospitality such as meals or token recognitions.

- The publication can be used by third parties. About the authors

Dr. Tecklah Usai is a lecturer in the Department of Food Science and Technology Design at the Midlands State University Gweru Zimbabwe. She has great research interest in human health, herbs and natural foods. She completed a BSc Degree in Home Economics in 2001, at Midlands State University, a MSc Degree with Education in Human Nutrition in 2009, University of Zimbabwe and PhD with Midlands State University in 2018. Dr Tecklah Usai has been awarded several merit certificates for teaching A level Food Science classes and she recieved a 10 Year Long lectureship award at Midlands State University, Zimbabwe.

Dr. Tafirenyika Mafugu works for the department of education in KwaZulu-Natal. He has great enthusiasm in nutrition, food science and human health. He completed a BSc in 1996, PGCE in 2000, and MED in Human Nutrition Education in the year 2009 at the University of Zimbabwe. In the year 2018, he obtained a PhD degree at the University of Fort Hare. He has received several awards for his outstanding work in the Department of Education in KwaZulu-Natal South Africa.

\section{REFERENCES}

1. Adamu, A., Adjei, N.K.G., \&Kubuga, C.K. (2012). Effects of Dietary Patterns on the Nutrition Status of Upper Primary School Children in Tamale Metropolis. Pakistan Journal of Nutrition, 11 (7): 689-707.

2. African Union. (2015). First Specialised Technical Meeting on Education, Science And Technology: Briefing Note- Home Grown School Feeding as a Driver of Local Development. Addis Ababa: African Union.

3. Aliyar R,Gelli A, \& Hamdani S.H. (2015). A Review of Nutritional Guidelines and Menu Compositions for School Feeding Programs in 12 Countries. Frontiers in public health, 3 (1):1-13.

4. Alters, S., \& Schiff, W. (2009). Essential Concepts for Healthy Living. ( $5^{\text {th }}$ ed.). Boston: Jones and Bartlett Publishers, LLC.

5. Altman, M., Hart, T., \& Jacobs, P. (2009). Household food security status in South Africa. Agrekon, 48 (4): 345-361.

6. Berdanier, C.D., Dwyer, J.T., \& Heber, D. (Eds.). (2014). Handbook of Nutrition and Food.London: CRC Press.

7. Buhl, A. (2010). Meeting Nutritional Needs Through School Feeding: A Snapshot of Four African Nations. Global Child Nutrition Foundation. http://www.gcnf.org/library/MeetingNutritional-Needs-Through-SchoolFeeding.pdf(accessed 10/04/2017).

8. Bundy, D., Woolnough, A., Burbano, C., \& Drake, L. (2016). Global School Feeding Sourcebook Lessons from 14 countries. London: Imperial College Press.

9. Caraher, M., \& Coveney, J. (Eds.). (2016). Food Poverty and Insecurity: International Food Inequalities. London: Springer.

10. CONDE NAST (2014). Vegetables, mixed (corn, lima, beans, peas, green beans, carrots). Nutritiondata.self.com/facts/vegetablesproducts/7657/2. (accessed 05/11/2017).

11. Department of Basic Education. (2009). National School Nutrition Programme: A guide for secondary schools. Pretoria: Department of Basic Education.

12. Department of Basic Education. (2016). National School Nutrition Programme. Pretoria: Department of Basic Education.

13. Embuscado, M.E. (Ed.). (2014). Functionalizing Carbohydrates for Food Applications: Texturizing 
Tafirenyika Mafugu and Tecklah Usai, IJFNR, 2019; 3:25

and Bioactive/Flavor Delivery Systems. Lancaster: DEStech Publications, In.

14. Food and Agriculture Organisation of the United Nations. (2016). Sierra Leone Food Based Dietary Guidelines for Healthy Eating.http://www.siera-leone-food-based dietary-guidelines-for-healthy-eating.pdf (accessed 10/03/2017).

15. Hayes, D., \& Berdan, G. (2013). School nutrition programs: challenges and opportunities.http://www.sizediversityandhealth.o rg/images/uploaded/2013\%20School\%20Nutritio n\%20AJLM\%20(Hayes-Berdan).pdf (accessed 15 August 2016).

16. Health24, (2016). Micronutrient deficiencies rife in developing countries.www.health24.com/Dietand-nutrtion/Nutrition-basics/Micronutrientdeficiencies-rife-in-developing- countries20160824 (accessed 11/04/2017).

17. Hochfeld, T., Graham, L., Stuart, L., \& Gent, M.Y. (2015). Evaluation Study of the National School Nutrition Programme and the Tiger Brands Foundation In-School Breakfast Feeding Programme in the Lady Frère and Qumbu Districts of the Eastern Cape. Johannesburg: Centre for Social Development in Africa, University of Johannesburg.

18. Joshi, S.A. (2010). Nutrition and Dietetics (With Indian Case Studies). (3 ${ }^{\text {rd }}$ ed.). New Dehli: Tata McGraw Hill Education Private Limited.

19. Kallman K. (2005). Food for Thought: a review of the National School Nutrition Programme. Cape Town: Children's Institute.

20. Kessel, A., \& Ben-Tal, N. (2010). Introduction to proteins, structure, function and Motion. London: CRC Press.

21. Laar, M.E. (2016). School feeding programmes in Ghana. Agriculture, Nutrition and Health Academy.

http://anhacademy.org/blog/2016/04/07/school-

feeding-programmes-ghana.

22. Lacey, G. (2012). Guidebook to Education in the Commonwealth. London: Commonwealth Secretariat.

23. Marshall, W.J., Lapsley, M., Day, A.P., \& Ayling, R.M. (2014). Clinical Biochemistry E-Book: Meabolic and Clinical Aspects. (3 ${ }^{\text {rd }}$ ed.). London: Elsevier Limited.

24. Rendall-Mkosi, K., Wenhold, F., \& Sibanda, N.B. (2013). Case Study of the National School Nutrition Programme in South Africa. University of Pretoria. London: Partnership for Child Development.

25. Rudrappa, U. (2017). USDA Nationa Nutrient Database.

(http;//ndb.nal.usda.gov/ndb/foods/show/29197/.

26. Shisana, O., Labadarios, D., Rehle, T., Simbayi, I., Zuma, K.; Dhansay, A., Reddy, P., Parker, W., Hoosain, E., Naidoo, P., et al. (2014). South African National Health and Nutrition Examination Survey (SANHANES-I). Cape Town: HSRC Press.

27. Sizer, F. S., Piché, L. A., \& Whitney, E. N. (2012). Nutrition: Concepts and controversies. $\left(6^{\text {th }}\right.$ ed.). Toronto: Nelson Education.

28. South African Food Data System. (2015). SaMRC advancing life.Safoodsapps.mrc.ac.za/foodcomposition/. (accessed 05/11/2017)

29. Tathiah, N., Moodley, I., Mubaiwa, V., Denny, L., \& Taylor, M. (2013). South Africa's nutritional transition: Overweight, obesity, underweight and stunting in female primary school learners in rural KwaZuluNatal, South Africa. South African Medical Journal, 103 (10): 718-723.

30. United States Department of Agriculture. (2017). MyPlate.

31. http://www.choosemyplate.gov/MyPlate (accessed 13/03/2017).

32. Watson, R.R., \& Preedy, V.R. (Eds.). (2013). Bioactive food as dietary interventions for cardiovascular disease. Boston: Academic Press.

33. World Food Programme. (2016). School Meals. www.wfp.org/school-meals/wfp-school-meals (accessed 22/05/2016). 